\title{
Research on the Cross-regional Impact of FDI on the Upgrading of Industrial Structure Based on the Regulatory Effect of Industry Competition Intensity
}

\author{
Xu Xinmao \\ Financial Management of Southwest Petroleum University, Shunqing, Nanchong, Sichuan, China
}

\begin{abstract}
Under the background of all-round opening-up, this paper studies the influence mechanism of FDI on the upgrading of industrial structure and whether FDI affects the formation of industrial structure upgrading. Firstly, this study select the data of the country and three major economic regions as samples, which is based on a benchmark model, an effect adjustment model and an interactive cross-regional model; secondly, with the analysis of the data based on the above-mentioned models, the corresponding results are obtained: FDI promotes the industrial structure upgrade in China and the three major economic zones. Meanwhile, the industry competition caused by FDI exerts a significant influence in promoting the upgrading of the industrial structure. After research of the interactive cross-regional mechanism, it is concluded that there is a unilateral cross-regional influence between eastern region and central as well as western regions, and there is a bilateral cross-regional influence between central and western regions. In the end, based on the above results, this paper proposed development strategies and methods related to China's rational use of FDI and optimization of industrial structure upgrading.
\end{abstract}

\section{Introduction}

The Chinese economy is undergoing continuous development significantly under the profound changes and reforms of international situations. Investment foreign capital has become a major symbol of the development of economic globalization. With the continuous increase in China's comprehensive national strength and economic power, China has now become the second most attractive country for foreign investment. However, FDI is not being distributed fairly here. Specifically speaking, the distribution of FDI doesn't strike a balance among and inside regions. The proportion of foreign capital in the eastern region accounts for about $80 \%$ of the total FDI, while it in the central and western regions only accounts for $20 \%$. Among the three major economic zones in my country, the actual amount of FDI spent on the primary industry accounted for the smallest part, while the secondary and tertiary industries have long occupied a large proportion. Therefore, studying the impact of China's FDI level is of vital importance to the industrial structure and regionality.

Although there have been many opinions in the academic community about the research of FDI on the upgrading of industrial structure, a unified point of view and system remain to be formed. And experiences from some developed countries show that FDI could promote the upgrading of industrial structure in the host country, so that it can provide learning opportunities for the host country, and the real improvement is determined by the effort the host country makes itself in absorbing and transforming advanced technology and experience for its own use, instead of simply imitating or blindly following the crowd. Higher quality of innovations might promote the progressing and upgrading of the industrial structure efficiently based on above analysis. For the time being, most scholars in China and foreign countries tend to study whether FDI will exert spillover effects on technological innovation, and they conduct research based on this industry. However, there is not much literature on the upgrading of the industrial structure of the host country by FDI at the regional level. Therefore, selecting national and regional levels as the starting points, this thesis aims at exploring the cross-regional impact of FDI on the upgrading of industrial structure from these two aspects, conducting adjustment tests, analyzing the spillover effect of the region, and providing relevant strategies and suggestions on promoting the upgrading of industrial structure.

The rest of this paper includes: related research work and thesis hypotheses are introduced in Chapter 2; the relevant variables and data sources used in this thesis are introduced in Chapter 3; the model and experimental analysis results are developed, the benchmark regression model and the test results of the adjustment effect are analyzed in Chapter 4; Chapter 5 makes conclusions based on the empirical analysis results obtained, and puts forward suggestions and opinions on accelerating the upgrading and optimization of the industrial structure; the last part is the reference. 


\section{Literature review and analysis of influence mechanism}

\subsection{Literature review}

As to the role of FDI in the upgrading of industrial structure, two major views are popular in the academic academy. Some scholars think that FDI affects the upgrading of industrial structure in a positive way. Caves (1974) used manufacturing data from Australia and Canada to study the relationship between corporate profits and FDI, and they also showed that FDI can promote the increase of profits and accelerate the optimization of the industrial structure.[1] Hirschman (1970) further introduced the concept of "technical gap" and discussed deeper the impact of introducing FDI on the economic development and industrial structure adjustment and upgrading of the host country. [2] Wen Dongwei et al. (2009) studied that foreign companies, with investment and technology, promoted the transfer of China's production activities from labor-intensive industries to capital and technology-intensive industries, thereby optimizing and upgrading the industrial structure.[3] Qiong and Minyu (2013) used time series data from 1990 to 2009 in China to empirically analyze that FDI inflows promotes the industrial total factor productivity. Among them, the primary industry benefited from it the most, followed by the secondary and the tertiary industry.[4]

However, recently, some scholars hold that FDI also prevents the upgrading of industrial structure. Niu Weiping (2012) thinks that the introduction of FDI will cause China to fall into a "comparative advantage trap", which can only develop low-end industries whose added value is low, restraining the upgrading of China's industrial structure. [5] Zhang Ping (2016) mentioned in his research that the sustaining increase in foreign direct investment has suppressed the increase in the proportion of China's service industry and posed some threat to the transformation and upgrading of its industrial structure. [6] Zhao Lei et al. (2018) believe that the efficiency of financial development restricts the process of FDI's influence on the upgrading of industrial structure. [7] An increase in the efficiency of financial development means that there will be less impact of FDI on the upgrading of industrial structure.

Although the above literature has conducted a more detailed analysis of the impact of FDI on the upgrading of industrial structure, most of which are conducted according to the macro perspective of the three major industries, aiming at illustrating the changes in a country's industrial structure. However, most of literature are failed in further exploring the inter-regional industry, and the situation of structural upgrading also seldom involves the interaction influence of FDI on the upgrading of industrial structure at the regional level. Therefore, according to the above-mentioned research, by analyzing the specific impact paths of FDI at the national level and in the three major economic regions on the upgrading of industrial structure, exploring whether the introduction of foreign investment in my country promotes and how to promote the upgrading of industrial structure, and further studying the impact of FDI on the upgrading of industrial structure, and whether there are cross-regional interactions in every economic zone, this thesis puts forward relevant strategies and paths for the sound upgrading of China's industrial structure and the persistent development of the economy and society.

\subsection{Assumptions}

From the national and regional perspectives, this paper conducts a research on the influence mechanism of FDI on the upgrading of industrial structure and whether FDI causes an interactive cross-regional impact on forming industrial structure upgrading. Nevertheless, the following assumptions are proposed:

(1) FDI promotes the upgrading of industrial structure.

(2) The intensity of industry competition can moderate the process of FDI's influence on the upgrading of the industrial structure.

(3) FDI causes an interactive and cross-regional impact on the upgrading of industrial structure.

\section{Data Selections and Modelling Process}

\subsection{Data sources}

In this paper, we use the panel data from 31 provinces in Mainland China from 2000 to 2019, empirical research is conducted in this paper. To study the cross-regional impact of FDI on the upgrading of industrial structure, relevant data is retrieved from China Statistical Yearbook from the previous years. For the purpose of guaranteeing the accuracy of the test results, the original data is processed by natural logarithm.

\subsection{Variables selection}

\subsubsection{Explained variables}

Industrial structure upgrade $(y)$ : Based on the current experience in the development of international economy and industrial structure, we should note that whether there is an increase on the proportion of tertiary industry on a country or region's GDP if we want to know whether a country or region's industrial structure is transformed and upgraded. Since there is no international standard for the measurement of this industrial structure optimization index, this thesis adopts Kuznets tertiary industry proportion standard, which is a frequently used measurement means around the world. It chooses the ratio of the tertiary industry to GDP y as an indicator measuring the upgrading of the country's industrial structure.

\subsubsection{Core explained variables}

FDI: FDI is an indicator of foreign direct investment. In this article, most of the measurement of FDI adopts the amount of foreign investment actually used as a substitute index for FDI, which is directly recorded as FDI. 


\subsubsection{Absorptive capacity variables}

(1) Human capital (hum): In general, the higher the level of human capital, the more frequently the mobility of labor within the industry and the higher the efficiency of resource allocation. This proves that human capital is a vital influence in the upgrading of industrial structure. This article chooses the method of education years, which calculates the proportion of each province's weighted total time of education to the total population each year.

(2) Technological innovation (tec ): Technological progress serves as the internal impetus for the upgrading of industrial structure. Improvement on technological innovation is beneficial to improvement on labor productivity, and achievement of the transformation and upgrading of the industrial structure. This article measures technological progress from three types of domestic patent applications.

\subsubsection{Adjusted variables}

Industry competition intensity ( $\mathrm{com}$ ): The degree of market monopoly depends on the number of companies in the industry. Monopoly companies are usually inefficient when being compared with companies in an effective competitive environment, resulting in a waste of resources. The industry competition effect of FDI, with the means of an increase on market competition pressure, eliminated monopoly to some extent, stimulated the competitiveness of individual industries, and promoted the upgrading of industrial structure. Therefore, during the process of FDI influencing the industrial structure, firstly, the increase in the intensity of industry competition enables the industry to prevent itself from inefficiency, contributing to an effective competitive market, so as to compete with multinational companies. As to the industrial structure, the upgrading and optimization of the industrial structure is the foundation of profitability. With the inflow of FDI, it will inevitably threaten the survival and development of local enterprises. Then, the competing industries will inevitably improve their own technological levels more actively, increase R\&D investment, and carry out selfupgrading. Referring to Zhan Jie, (2020) use the method of measuring the intensity of industry competition, this thesis selects the ratio of the industrial added value of each industry in the high-tech industry to the number of enterprises, and divides the ratio by the sum of the average values of all manufacturing industries to measure the intensity of industry competition.[8]

\subsubsection{Control variables}

The upgrading of industrial structure is not only influenced by the above core explained variables, but also by many other factors. Learning from the research results of other scholars on the factors influencing industrial structure upgrading, taking into consideration the availability of data and the unity of indicators, this thesis selects the following control variables:

(1) Infrastructure construction ( con ): Select the number of railways per capita in each province.
(2) The degree of government support ( $g o v$ ): Select the percentage of provincial government fiscal expenditure to GDP.

\begin{tabular}{|c|c|c|c|}
\hline Variable & Index & Symbol & Explanation \\
\hline $\begin{array}{l}\text { Explained } \\
\text { variable }\end{array}$ & $\begin{array}{l}\text { Industrial } \\
\text { structure } \\
\text { upgrade }\end{array}$ & $y$ & $\begin{array}{l}\text { Ratio of tertiary } \\
\text { industry to GDP }\end{array}$ \\
\hline $\begin{array}{c}\text { Explanatory } \\
\text { variable }\end{array}$ & $\begin{array}{c}\text { Foreign } \\
\text { Direction } \\
\text { Investment }\end{array}$ & $F d i$ & $\begin{array}{c}\text { Actual utilization } \\
\text { of foreign } \\
\text { investment }\end{array}$ \\
\hline \multirow[t]{2}{*}{$\begin{array}{l}\text { Absorptive } \\
\text { capacity }\end{array}$} & Human capital & hum & $\begin{array}{l}\text { Annual weighted } \\
\text { total time of } \\
\text { education as a } \\
\text { proportion of the } \\
\text { total population in } \\
\text { each province }\end{array}$ \\
\hline & $\begin{array}{l}\text { Technological } \\
\text { innovation }\end{array}$ & tec & $\begin{array}{l}\text { Applying times of } \\
\text { three types of } \\
\text { domestic patents }\end{array}$ \\
\hline \multirow[t]{2}{*}{$\begin{array}{c}\text { Moderating } \\
\text { variable }\end{array}$} & $\begin{array}{l}\text { Industry } \\
\text { competition } \\
\text { intensity }\end{array}$ & com & $\begin{array}{l}\text { Ratio of the } \\
\text { industrial added } \\
\text { value of each } \\
\text { industry in the } \\
\text { high-tech industry } \\
\text { to the number of } \\
\text { enterprises } \\
\text { divided by the } \\
\text { sum of the } \\
\text { average of all } \\
\text { manufacturing } \\
\text { industries }\end{array}$ \\
\hline & $\begin{array}{l}\text { Basis } \\
\text { Infrastructure } \\
\text { construction }\end{array}$ & con & $\begin{array}{l}\text { Number of } \\
\text { railways per capita } \\
\text { in each province }\end{array}$ \\
\hline $\begin{array}{c}\text { Control } \\
\text { variables }\end{array}$ & $\begin{array}{l}\text { Government } \\
\text { support level }\end{array}$ & gov & $\begin{array}{c}\text { Proportion of } \\
\text { provincial } \\
\text { government fiscal } \\
\text { expenditure in } \\
\text { GDP }\end{array}$ \\
\hline
\end{tabular}

\subsection{Model setting}

\subsubsection{Benchmark regression model}

Some researches on the literature industrial structure are conducted according to the construction of an industrial structure upgrading index or an industrial structure adjustment index. The three major economic regions in China are not studied separately, while the general orientation of industrial structure adjustment is obtained, also there are few researches on the specific changes in each economic region. Thus, for the purpose of evaluating the cross-regional impact of FDI on China's industrial structure, this article has conducted research on China's three major economic regions and constructed the following models: 


$$
\begin{aligned}
\ln y_{i t}= & a_{0}+a_{1} \ln F D I_{i t}+a_{2} \ln \text { hum }_{i t}+a_{3} \ln t e c_{i t} \\
& +a_{4} \ln \text { Control }_{i t}+\theta_{i t}
\end{aligned}
$$

Among them, $i$ represents the region and $t$ represents the year. The industrial structure upgrade is the logarithm of the proportion of tertiary industry in GDP of the whole country and each economic zone $i$ at $t$, the logarithm of the total foreign direct investment of area $i$ at $t$, and the difference of the human capital level of area $i$ at $t$ is the logarithm of the technological innovation of region $i$ at $t$, and is the logarithm of the control variable, which are infrastructure construction (con) and government support $(g o v)$, respectively, and $\theta$ it is the error term.

\subsubsection{Regulation model}

Based on the previous mechanism research and hypothesis, in the paper we argue that FDI will exert an impact on the upgrading of industrial structure by the means of industry competition intensity ( $\mathrm{com}$ ), thus the benchmark model is further expanded and the following model is established:

$$
\begin{aligned}
\ln y_{\mathrm{it}} & =b_{0}+b_{1} \ln F D I_{i t}+b_{2} \ln \text { hum }_{i t}+b_{3} \ln t e c_{i t} \\
& +b_{4} \ln \mathrm{con}_{i t}+b_{5} \ln \operatorname{gov}_{i t}+b_{6} \ln \operatorname{com}_{i t} \\
& +b_{7} \ln F D I_{i t} * \ln \operatorname{com}_{i t}+\varphi_{i t}
\end{aligned}
$$

\section{Empirical results and analysis}

\subsection{Correlation analysis}

Correlation analysis is the analysis of two or more correlated variables, so as to judge the closeness level between the variables. In case there is a low correlation between the variables, it can be judged that there is no practical significance for the relationship between the

\begin{tabular}{|c|c|c|c|c|c|c|}
\hline & $\operatorname{lnFDI}$ & lnhum & lntec & lncom & lngov & lncon \\
\hline $\operatorname{lnFDI}$ & 1 & & & & & \\
\hline lnhum & 0.6577 & 1 & & & & \\
\hline lntec & 0.6657 & 0.5989 & 1 & & & \\
\hline lncom & 0.5258 & 0.5383 & 0.5803 & 1 & & \\
\hline lngov & 0.6625 & 0.5670 & 0.6523 & 0.5356 & 1 & \\
\hline Incon & 0.3139 & 0.5706 & 0.4222 & 0.5132 & 0.4241 & 1 \\
\hline
\end{tabular}
variables of this type. With Eviews7.2 software, this paper conducts a simple correlation analysis on the main variables of the country and each economic zone from 2000 to 2019, and the results are displayed in Table 2.

In view of the data in the above table, we can conclude that the correlation coefficient between the main variables is between 0.4-0.7. It can be initially considered that there is no multicollinearity problem among the major variables, and further analysis and attempts are needed to reveal that the relationship between the variables is of feasible and economic significance.

\subsection{Unit root test}

For the purpose of conducting regression analysis, we should carry out unit root tests on the data of the main variables of the country and the three economic zones from 2000 to 2019 , in order to verify the stability of the time series data and prevent false regression problems.

This article uses the ADF inspection method in Eviews 7.2 software. After testing, it is found that after the main variables are processed by first-order difference, the

\begin{tabular}{|c|c|c|c|c|}
\hline Variable & National & East & Central & West \\
\hline lny" & $-4.5326 * * *$ & $-4.3389 * * *$ & $-4.4567 * * *$ & $-3.4681 * * *$ \\
\hline lnFDI" & $-2.6998 * * *$ & $-2.4101 * * *$ & $-2.0404 * * *$ & $-2.1404 * * *$ \\
\hline lnhum" & $-3.5398 * * *$ & $-3.9759 * * *$ & $-3.4328 * * *$ & $-3.7932 * * *$ \\
\hline lntec" & $-3.8855 * * *$ & $-8.9045 * * *$ & $-6.5794 * * *$ & $-7.5864 * * *$ \\
\hline lncom" & $-2.7964 * * *$ & $-3.9991 * * *$ & $-4.3822 * * *$ & $-3.5417 * * *$ \\
\hline $\ln g o v "$ & $-5.2636^{* * *}$ & $-4.6047 * * *$ & $-9.2241 * * *$ & $-2.4574 * * *$ \\
\hline lncon" & $-6.1942 * * *$ & $-4.0900 * * *$ & $-5.6000 * * *$ & $-4.5280 * * *$ \\
\hline
\end{tabular}
test results reject the null hypothesis containing unit roots, that is, it is unstable, indicating that variables maintain a long-term stable equilibrium relationship, so the panel analysis can be directly performed.

Note: " is the symbol for the first-order difference. $* * *$, $* *$, and $*$ are significantly below the levels of $1 \%, 5 \%$, and $10 \%$, respectively. The same below.

\subsection{Benchmark model regression}

Based on analysis mentioned above, the relevant data are processed and analyzed with Eviews7.2. The regression results are shown in Table 4.

Table4. Benchmark regression results of FDI's impact on industrial upgrading

\begin{tabular}{ccccc}
\hline Variable & $\begin{array}{c}\text { National } \\
\text { sample }\end{array}$ & $\begin{array}{c}\text { Eastern } \\
\text { sample }\end{array}$ & $\begin{array}{c}\text { Central } \\
\text { sample }\end{array}$ & $\begin{array}{c}\text { Western } \\
\text { sample }\end{array}$ \\
\hline C & 0.0589 & 0.4883 & 0.0399 & 0.0414 \\
& & & & \\
lnFDI & $0.0088^{* *}$ & $0.0555^{* * *}$ & $0.0315^{* * *}$ & $0.0078^{* *}$ \\
& $0.0318^{* *}$ & $0.0412^{* * *}$ & $0.0430^{*}$ & $0.0452^{* * *}$ \\
lnhum & $*$ & & & \\
lntec & $0.0067^{*}$ & $0.0587^{* * *}$ & $0.0111^{* * *}$ & $0.0072^{*}$ \\
lncon & $0.0232^{* *}$ & $0.0281^{*}$ & $0.0457^{* * *}$ & $0.0253^{* * *}$
\end{tabular}




$\begin{array}{ccccc}\text { lngov } & 0.0087^{*} & 0.0924 * * * & 0.0455^{* * *} & 0.0184^{* *} \\ & & & & \\ F & 465.8121 & 182.4919 * & 344.1481 * & 384.3203 * \\ & * * * & * * & * * & * * \\ R^{2} & 0.9940 & 0.9849 & 0.9919 & 0.9928\end{array}$

(1) Analysis at the national level

The results indicate that FDI promotes the upgrading of China's industrial structure actively, that is, the more FDI there is, the more it can promote the process of industrial structure upgrading. First of all, the entry of multinational companies can provide new vitality to the market.[9] To dominate the market, they will take the initiative to bring in competitive new products and technologies, thus promoting the innovation of China's industry and leading China's industrial structure to a higher level. This is the direct impact of the inflow of FDI on the upgrading of China's industrial structure; In addition, for the upgrading of China's industrial structure itself, the inflow of FDI offers good learning and observation opportunities for local industries. It provides thinking and development direction for upgrading of industry, which can effectively avoid the problems of rigid thinking and insufficient innovation due to the externalities of knowledge and technology.[10] Finally, the human capital level and technological innovation level has significantly positive impact, proving that human capital and technological innovation are vital carriers for FDI to come into play in the upgrading of industrial structure, which can facilitate the upgrading of industrial structure.

(2) Analysis at the regional level

In terms of regions, FDI significantly promotes the upgrading of the industrial structure in various regions, but its power is different among regions obviously, which means the power of the eastern, central, and western regions are declining. The eastern region enjoys a sound industrial basis, extensive government support, and rich FDI resources, which provide corresponding guarantees for the upgrading of the industrial structure there. However, the level of human capital in the western region plays a relatively obvious positive role. Probably because of the large-scale development of the western region and the Belt and Road Initiative in recent years, as well as the expected unimpeded domestic and foreign dual circulation, some high-quality talents have been affected by the "talent introduction" policy, therefore, they devote themselves to constructing the western regions. The level of infrastructure construction in the central region is also obviously better than the eastern and western regions. This is because the central region has always been an important area for the construction of large corridors and hubs in China, and it serves as a bridge between east and west, south and north.[11]

(3) Analysis of control variables

It can be concluded from the regression results of the control variables: the government support and the level of infrastructure exert a vital positive influence on the industrial structure upgrading. Road transportation and informatization as well as other infrastructure can be directly put into the production process, which can further facilitate upgrading of industrial structure. [12] For a long time, the government has provided preferential conditions and financial support for China related industries by attracting business and investment, which is beneficial to the upgrading of China's industrial structure. Therefore, the government support yielded relatively significant positive effects. The construction of a sound infrastructure has a significant role in improving production efficiency and lowering production costs, which in turn can promote the upgrading of China's industrial structure.

\subsection{Moderating effect test}

As shown in the table 5, since putting the industry competition intensity and the crossover terms of FDI and industry competition intensity into the regression of the benchmark model, the coefficients are all significantly positive, and the estimated standard deviations of the country and each region are reduced to various degrees, that is, the overall fit of the model has been improved, which can strengthen the interpretation of the upgrading of the industrial structure. It shows that after introducing market competition, the bring in of foreign-funded enterprises will inevitably intensify industrial competition. To retain their technological superiority when confronting more fierce market competition, not only foreign-funded enterprises but also local enterprises in the host country will actively increase their R\&D investment, accelerate the progress of technological development and strengthen its own corporate management capabilities, so as to improve the overall industrial technology level and the evolution of the entire industrial structure.[13]

Table5. Regression results of the moderating effect of industry competition intensity

\begin{tabular}{|c|c|c|c|}
\hline Variable & $\begin{array}{c}\text { Before } \\
\text { adjustment }\end{array}$ & $\begin{array}{c}\text { After } \\
\text { adjustment }\end{array}$ & $\begin{array}{c}\text { After } \\
\text { adjustment }\end{array}$ \\
\hline$C$ & 0.0589 & 0.0141 & 0.1050 \\
\hline \multirow{2}{*}{$\ln F D I$} & $0.0088 * *$ & $0.0122 * * *$ & $0.1050 * * *$ \\
\hline & $(0.0044)$ & $(0.0037)$ & $(0.0027)$ \\
\hline \multirow[b]{2}{*}{ lnhum } & $0.0318 * * *$ & $0.0381 * * *$ & $0.0421 * * *$ \\
\hline & $(0.0047)$ & $(0.0043)$ & $(0.0029)$ \\
\hline \multirow[b]{2}{*}{ lntec } & $0.0067^{*}$ & $0.0062 * *$ & $0.0046^{* * *}$ \\
\hline & $(0.0039)$ & $(0.0031)$ & $(0.0020)$ \\
\hline \multirow[b]{2}{*}{ lncon } & $0.0232 * *$ & $0.0221 * * *$ & $0.0236^{* * *}$ \\
\hline & $(0.0115)$ & $(0.0092)$ & $(0.0059)$ \\
\hline \multirow[b]{2}{*}{ lngov } & $0.0087^{*}$ & $0.0125 * *$ & $0.0149 * * *$ \\
\hline & $(0.0107)$ & $(0.0087)$ & $(0.0055)$ \\
\hline lncom & & $0.0175 * *$ & $0.0711 * * *$ \\
\hline
\end{tabular}




\begin{tabular}{|c|c|c|c|c|c|c|c|}
\hline & & $(0.0059)$ & $(0.0024)$ & & $(0.0072)$ & $(0.0063)$ & $(0.0052)$ \\
\hline \multirow{3}{*}{$\begin{array}{l}\text { lncom } \\
* \ln F D I\end{array}$} & & & $0.0990 * * *$ & \multirow{3}{*}{ lntec } & $0.0111 * *$ & $0.0142 * *$ & $0.0222 * * *$ \\
\hline & & & & & & & \\
\hline & & & $(0.0219)$ & & $(0.0110)$ & $(0.0102)$ & $(0.0072)$ \\
\hline $\mathrm{F}$ & $465.8121 * * *$ & $602.5931 * * *$ & $1286.569 * * *$ & \multirow{3}{*}{ lncon } & $0.0457 * * *$ & $0.0453 * *$ & $0.0485^{* * *}$ \\
\hline & & & & & & & \\
\hline $\mathrm{R}^{2}$ & 0.9940 & 0.9964 & 0.9987 & & $(0.0059)$ & $(0.0058)$ & $(0.0037)$ \\
\hline \multicolumn{4}{|c|}{$\begin{array}{l}\text { Table6. Regression results of the moderating effect of the } \\
\text { intensity of industrial competition in the eastern region }\end{array}$} & \multirow[t]{2}{*}{ lngov } & $0.0455^{* * *}$ & $0.0409 * * *$ & $0.0393 * * *$ \\
\hline \multirow{2}{*}{ Variable } & Before & After & After & & $(0.0116)$ & $(0.0112)$ & $(0.0079)$ \\
\hline & adjustment & adjustment & adjustment & \multirow[t]{2}{*}{ lncom } & & $0.0134 * * *$ & $0.2501 * * *$ \\
\hline C & 0.4883 & 0.4788 & $0.5201 * * *$ & & & $(0.0121)$ & $(0.0118)$ \\
\hline \multirow{2}{*}{$\operatorname{lnFDI}$} & $0.0555^{* * *}$ & $0.0656^{* * *}$ & $0.2211 * * *$ & \multirow{2}{*}{$\begin{array}{l}\text { lncom } \\
* \ln F D I\end{array}$} & & & $0.1551 * * *$ \\
\hline & $(0.0196)$ & $(0.0188)$ & $(0.0161)$ & & & & $(0.0132)$ \\
\hline \multirow{2}{*}{ lnhum } & $0.0412 * * *$ & $0.0424 * * *$ & $0.0522 * * *$ & F & $344.1481^{* * *}$ & $291.4431 * * *$ & $651.5238^{* * *}$ \\
\hline & $(0.0094)$ & $(0.0087)$ & $(0.0081)$ & $\mathrm{P}^{2}$ & & & \\
\hline \multirow[b]{2}{*}{ lntec } & $0.0587 * * *$ & $0.0573 * * *$ & $0.0394 * * *$ & & & & \\
\hline & $(0.0205)$ & $(0.0188)$ & $(0.0170)$ & \multicolumn{4}{|c|}{$\begin{array}{l}\text { Table8. Regression results of the moderating effect of } \\
\text { industrial competition intensity in the western region }\end{array}$} \\
\hline \multirow{3}{*}{ lncon } & $0.0281 *$ & $0.0248 * *$ & $0.0350 * * *$ & Variable & $\begin{array}{c}\text { Before } \\
\text { adjustment }\end{array}$ & $\begin{array}{c}\text { After } \\
\text { adjustment }\end{array}$ & $\begin{array}{c}\text { After } \\
\text { adjustment }\end{array}$ \\
\hline & & & & & & & \\
\hline & $(0.0144)$ & $(0.0136)$ & $(0.0120)$ & $C$ & 0.0414 & 0.0787 & 0.2579 \\
\hline \multirow[b]{2}{*}{$\operatorname{lngov}$} & $0.0924 * * *$ & $0.0901 * * *$ & $0.0829 * * *$ & \multirow[b]{2}{*}{$\ln F D I$} & $0.0078^{* *}$ & $0.0130 * * *$ & $0.1536^{* * *}$ \\
\hline & $(0.0187)$ & $(0.0172)$ & $(0.0145)$ & & $(0.0057)$ & $(0.0050)$ & $(0.0037)$ \\
\hline \multirow[t]{2}{*}{ lncom } & & $0.0131 *$ & $0.0915 * * *$ & \multirow[b]{2}{*}{ lnhum } & $0.0452 * * *$ & $0.0443 * * *$ & $0.0364 * * *$ \\
\hline & & $(0.0069)$ & $(0.0304)$ & & $(0.0082)$ & $(0.0080)$ & $(0.0060)$ \\
\hline \multirow{2}{*}{$\begin{array}{l}\text { lncom } \\
* \operatorname{lnFDI}\end{array}$} & & & $0.1684 * * *$ & \multirow[b]{2}{*}{ lntec } & $0.0072 *$ & $0.0070 * *$ & $0.0107 * * *$ \\
\hline & & & $(0.0642)$ & & $(0.0060)$ & $(0.0059)$ & $(0.0043)$ \\
\hline F & $182.4919 * * *$ & $181.2954 * * *$ & $226.7573 * * *$ & \multirow{2}{*}{ lncon } & $0.0253 * * *$ & $0.0256^{* * *}$ & $0.0339^{* * *}$ \\
\hline $\mathrm{R}^{2}$ & 0.9849 & 0.9882 & 0.9925 & & $(0.0083)$ & $(0.0080)$ & $(0.0061)$ \\
\hline \multicolumn{4}{|c|}{$\begin{array}{l}\text { Table7. Regression results of the moderating effect of } \\
\text { industry competition intensity in the central region }\end{array}$} & \multirow[t]{2}{*}{ lngov } & $0.0184 * *$ & $0.0125 * *$ & $0.0139 * * *$ \\
\hline \multirow[t]{2}{*}{ Variable } & $\begin{array}{c}\text { Before } \\
\text { adjustment }\end{array}$ & $\begin{array}{c}\text { After } \\
\text { adjustment }\end{array}$ & $\begin{array}{c}\text { After } \\
\text { adjustment }\end{array}$ & & $(0.0085)$ & $(0.0082)$ & $(0.0063)$ \\
\hline & & & & \multirow[t]{2}{*}{ lncom } & & $0.0194 * *$ & $0.2434 * * *$ \\
\hline$C$ & 0.0399 & 0.0608 & $0.2931^{* * *}$ & & & $(0.0150)$ & $(0.0061)$ \\
\hline \multirow{2}{*}{$\ln F D I$} & $0.0315^{* * *}$ & $0.0331 * *$ & $0.1908^{* * *}$ & \multicolumn{2}{|l|}{ lncom } & & $0.1415^{* * *}$ \\
\hline & $(0.0060)$ & $(0.0058)$ & $(0.0034)$ & $* \ln F D I$ & & & $(0.0177)$ \\
\hline lnhum & $0.0430^{*}$ & $0.0091 * * *$ & $0.0084 * * *$ & & & & \\
\hline
\end{tabular}




$\begin{array}{cccc}\mathrm{F} & 384.3203^{* * *} & 335.7421^{* * *} & 578.2565^{* * * *} \\ \mathrm{R}^{2} & 0.9928 & 0.9936 & 0.9970\end{array}$

\section{The mechanism test of the cross- regional impact of FDI on the upgrading of China's industrial structure}

In order to further explore whether FDI has an interactive and cross-regional influence on the upgrading of China's industrial structure at the regional level, this thesis conducts tests with the method of exchanging sample data one by one. The conclusions are as follows:

(1) There are unilateral and cross-regional effects between the eastern and central district. Selecting the industrial structure upgrading index of the eastern region as the explanatory variable, and test it with the data of the central and western regions respectively, it is found that the industrial structure upgrading of the eastern region has an obvious positive correlation with the central and western regions. As a result, the eastern region of China is undergoing favorable economic development, and the industrial structure has gradually developed with its industries to be dominated by new manufacturing and service industries. Recently, our country has further increased its support for the transfer of foreign-funded industries to the central and western regions. The central and western regions have grasped a good opportunity to undertake the gradient transfer of eastern industries under the country's preferential policies. Moreover, through industrial transfer, the industrial structure upgrade in the eastern area has become increasingly effective in driving the central and western regions, and the vitality of market entities has been stimulated, speeding up the upgrading of the industrial structure in the central and western regions.

Table9. Test of unilateral interaction and cross-regional impact mechanism in eastern region

\begin{tabular}{cccc}
\hline $\begin{array}{c}\text { Central } \\
\text { variable }\end{array}$ & $\begin{array}{c}\text { Eastern } \\
\text { sample }\end{array}$ & $\begin{array}{c}\text { Western } \\
\text { variable }\end{array}$ & $\begin{array}{c}\text { Eastern } \\
\text { sample }\end{array}$ \\
\hline C & 0.4053 & $C$ & 0.2144 \\
InFDI & $0.2736^{* * *}$ & lnFDI & $0.0869^{* * *}$ \\
Inhum & $0.0216^{* * *}$ & lnhum & $0.0145^{* * *}$ \\
Intec & $0.0237^{* * *}$ & lntec & $0.0452^{* * *}$ \\
Incon & $0.0576^{* * *}$ & lncon & $0.0311^{* * *}$ \\
lngov & $0.3389^{* * *}$ & lngov & $0.0251^{* * *}$ \\
lncom & $0.0601^{* *}$ & lncom & $0.1532^{* * *}$
\end{tabular}

\begin{tabular}{cccc}
\hline $\begin{array}{l}\text { lncom } \\
* \text { lnFDI }\end{array}$ & $0.2148^{* *}$ & $\begin{array}{l}\text { lncom } \\
* \ln F D I\end{array}$ & $0.0536^{* *}$ \\
$\mathrm{~F}$ & $421.2049^{* * *}$ & $\mathrm{~F}$ & $274.2824 * * *$ \\
$\mathrm{R}^{2}$ & 0.9959 & $\mathrm{R}^{2}$ & 0.9938 \\
\hline
\end{tabular}

(2) There is a mutual cross-regional interaction mechanism between the central region and the western region. Exchanging and testing the explained variables and explanatory variables in the central and western regions separately, we can notice that there is a synergistic effect between the industrial upgrading in the central and western regions. The economic development level of the central and western regions relatively lags behind, and its industrial structure remains at a lower level. Under the strategic guidance of the national policy "Western Development" and "Central Region Rise", the central and western regions have reinforced the improvement on the business environment for foreign businesses, broadened the channels for introducing foreign capital, gathered high-quality talents, and continuously improved industrial technology and innovation. The central and western regions learn from each other in the industrial structure, learn from each other's strengths in the use of foreign capital, ultimately realizing mutual benefits.

Table10. Inspection of the bilateral interaction and crossregional impact mechanism in the central and western regions

\begin{tabular}{|c|c|c|c|}
\hline $\begin{array}{l}\text { Central } \\
\text { variable }\end{array}$ & $\begin{array}{l}\text { Western } \\
\text { sample }\end{array}$ & $\begin{array}{l}\text { Western } \\
\text { sample }\end{array}$ & $\begin{array}{l}\text { Central } \\
\text { sample }\end{array}$ \\
\hline$C$ & 0.2061 & $C$ & 0.4132 \\
\hline $\ln F D I$ & $0.1265 * * *$ & $\ln F D I$ & $0.2430 * * *$ \\
\hline lnhum & $0.0313 * * *$ & lnhum & $0.0291 * * *$ \\
\hline lntec & $0.0245 * * *$ & lntec & $0.0121 * *$ \\
\hline lncon & $0.0418 * * *$ & lncon & $0.0312 * * *$ \\
\hline lngov & $0.0156^{* *}$ & lngov & $0.0249 * *$ \\
\hline lncom & $0.1791 * * *$ & lncom & $0.3892 * * *$ \\
\hline lncom & $0.1024 * * *$ & lncom & $0.2416^{* * *}$ \\
\hline$* \ln F D I$ & & $* \ln F D I$ & \\
\hline $\mathrm{F}$ & $953.4506 * * *$ & $\mathrm{~F}$ & $356.1059 * * *$ \\
\hline $\mathrm{R}^{2}$ & 0.9982 & $\mathrm{R}^{2}$ & 0.9952 \\
\hline
\end{tabular}

\section{Conclusions, suggestions and future research directions}

\subsection{Conclusion}

In this paper, with the means of empirical analysis, we analyze the mechanism of the impact of FDI on the 
upgrading of industrial structure, and tests the crossregional impact of FDI on the upgrading of China's manufacturing industry from the regional level, thus drawing the following conclusions:

Firstly, FDI exert a significant positive influence on the upgrading and progress of the industrial structures in China. With human capital and technological innovation as the carrier, foreign investment adjusts and allocates resources within the industry.

Secondly, industrial competition is brought by FDI, which serves as an impetus in the upgrading and progressing of industrial structure.

Thirdly, the industrial structure upgrade in the eastern region undergoes much faster improvement than the central and western regions, and there is a single-standard cross-regional interaction effect on the eastern and western regions; the industrial structure upgrade in the central and western regions have a mutual cross-regional interactive impact, manifesting there is a synergistic effect between the upgrading of industrial structure for the central and western regions.

\subsection{Development strategy and path}

First, China must firmly abide by the principle of "active choice" of FDI.

As China's demographic dividend gradually declines, China's attractiveness to FDI has also weakened to a certain degree However, China should not relax its "active choice" of FDI. Meanwhile, as the process of marketization accelerates, the role of FDI in promoting the upgrading of China's industrial structure may display a downward trend. [14] Therefore, China should start with its own economic development strategy and regional economic development plan.

The second is to achieve the strategic objective of optimizing the industrial structure and regional layout with the method of actively guiding the adjustment of the FDI structure.

Based on the principle of ensuring a fair competition in the market environment, through methods like strengthening policy support, etc., China should guide foreign investments in high-end industries, encourage foreign investments to build $R \& D$ centers, upgrade the industrial structure level, and promote the optimization and upgrading of the industrial structure; meanwhile, China should accelerate the improvement of the infrastructure foundation of the central and western regions, and enable the central and western regions to attract foreign investment and optimize the regional distribution of foreign investment, with the means of more favorable tax policies, etc. We must not only make the most out of the advantages of the developed eastern regions in terms of market, human resources, and infrastructure, but also make the most of the advantages of lower labor costs and land costs in the central and western regions, and actively lead foreign investment to high-end industries.

The third is to focus on improving independent innovation capabilities and cultivating innovative talents and enterprises.
The government should spread the idea of emphasizing innovation in the whole society, improve the innovation ability of people with various jobs; provide financial support and preferential policy for the technological innovation activities of local enterprises, actively guide the creation and development of innovative enterprises; stimulate the innovation vitality of the whole society, create a new style of innovation in the whole society.[15]

\subsection{Future research directions}

From the national and regional perspectives, this paper analyzes the influence of FDI on the upgrading of industrial structure. Meanwhile, we analyze the interaction and cross-regional mechanism of FDI on the upgrading of industrial structure with the three major economic regions. In the future, the research direction of this paper may focus on different industries, and differentiate between industries so as to analyze the effect of FDI on the upgrading of industrial structure.

\section{References}

1. CAVES,R.E.Multinational firms. Competition and Productivity in Host Country Market[J]. Economic,1974,41(5):176-193.

2. Hirschman A O.Exit, Voice, and Loyalty:Responses to Decline in Firms, Organizations, and States[J].Social Forces, 1970, 25 (1) :47-56.

3. Wen Dongwei, Xian Guoming, Ma Jing. FDI, Industrial Structure Changes and China's Export Competitiveness[J]. Management World,2009(4),96107.

4. Qiong Z,Minyu N. Influence Analysis of FDI on China's Industrial Structure Optimization[J]. Procedia Computer Science,2013,17:1015-1022.

5. Niu Weiping. Research on the Mechanism of International Outsourcing Trap and Its Leapfrogging[J]. China Industrial Economics, 2012 (5):109-121.

6. Zhang Ping. Does FDI Inhibit the Development of China's Service Industry? [J]. Economic Review, 2016 (5): 110-123+136.

7. Zhao Lei, Shao Mingxin, Bian Yingzi. The Impact of FDI on Industrial Structure Optimization under Different Financial Efficiencies - - An Empirical Study Based on Panel Data of 17 Cities in Shandong Province[J].East China Economic Management,2018(01):12-17.

8. Zhan Jie. Research on the Impact and Synergy of FDI on Technological Innovation in High-tech Industries[D]. University of Science and Technology of China, 2020.

9. Sun Zao, Han Ying. Foreign Direct Investment, Regional Differences and the Improvement of Independent Innovation Capabilities[J]. Economics and Management Research,2018(11):92-106.

10. Li Yuan, Ni Zhigang. An Empirical Study of Two-way FDI and Economic Growth: Taking Liaoning 
Province as an Example[J]. Journal of Shenyang University of Technology (Social Science Edition), 2018(2):120-126.

11. Lu Xiaoyong, Jin Yanqing. Analysis of the Influence of FDI Sole Proprietorship Based on Panel Data on Industrial Upgrading in Central China[J]. Journal of Nanchang University (Humanities and Social Sciences Edition), 2012, (9): 68-72.

12. AKBAR Y H, MCBRIDE J B.Multinational Enterprise Strategy,Foreign Direct Investment and Economic Development:The Case of the Hungarian Banking Industry[J].Journal of World Business, 2004,39(1):89-105.

13. Fu Yuanhai, Wang Xiaotong. Research on the Influence of Imitation and Competition Effects on the Optimization of Manufacturing Structure[J]. Auditing and Economic Research, 2018(4):105-115.

14. Gan Chunhui, Zheng Ruogu, Yu Dianfan. The Impact of China's Industrial Structure Changes on Economic Growth and Fluctuations[J]. Economic Research, 2011,46(05):4-16.

15. Stiebale, J., and Reize, F. 2012, The Impact of FDI through Mergers and Acquisitions on Innovation in Target Firms. International Journal of Industrial Organization, 29(2):155-167 